\title{
Figure S2
}

A

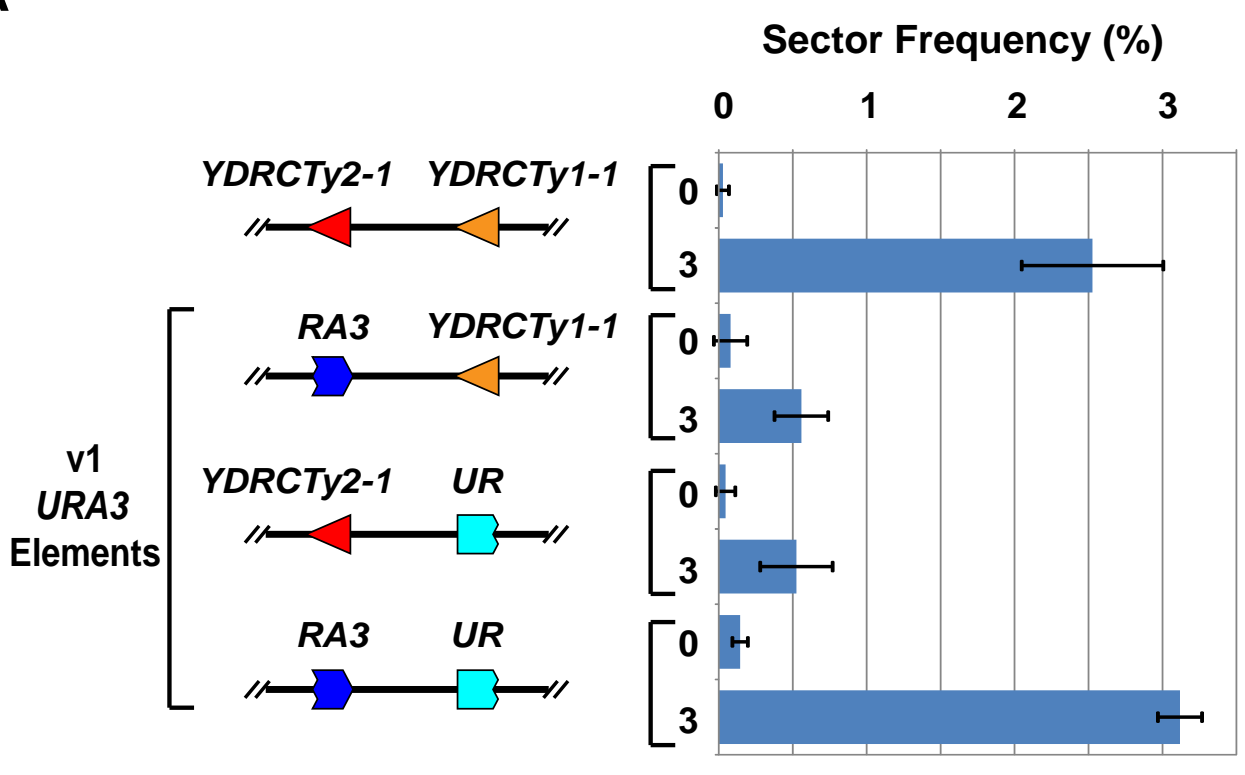

hrs

B

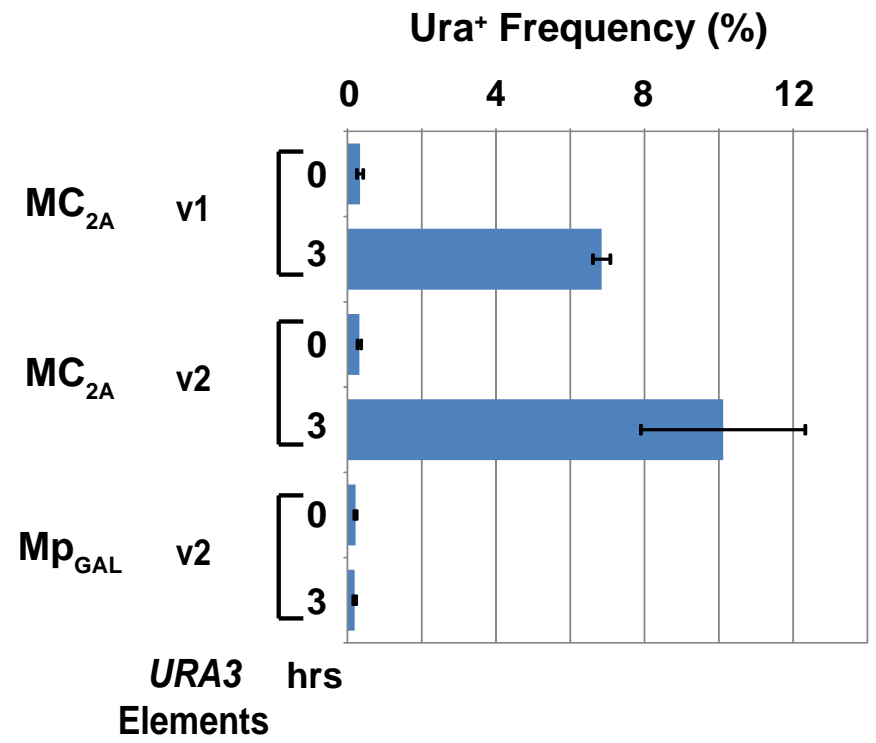

